\title{
ASSESSMENT OF GRASSLAND HEALTH BASED ON SPATIAL INFORATION TECHNOLOGY IN CHANGJI AUTONOMOUS PREFECTURE, XINJIANG
}

\author{
MJ. DU ${ }^{1}$, JH. Zheng ${ }^{1,2,3, *}$, C. $\mathrm{Mu}^{4}$ \\ ${ }^{1}$ College of Resource and Environment Science, Xinjiang University, Shengli Road 666, Urumchi, China - yukipine@ 163.com \\ ${ }^{2}$ Key Laboratory of Oasis Ecology Ministry of Education, Shengli Road 666, Urumchi, China - zheng_jianghua@ 126.com \\ ${ }^{3}$ Institute of Arid Ecology and Environment Xinjiang University, Shengli Road 666, Urumchi, China -zheng_jianghua@126.com \\ ${ }^{4}$ Xinjiang Uygur Autonomous Region Grassland Station, Yan'er Wo Road 618, Urumchi, China -396862688@qq.com
}

KEY WORDS: Health assessment, PSR model, RS technology, GIS technology, Entropy method

\begin{abstract}
:
Based on the "pressure-state-response"(PSR) model, comprehensively applied GIS and RS techniques, 20 evaluation indicators were selected based on pressure, state and response, the entropy weight method was used to determine the weight of each index and build a grassland health evaluation system in Changji Prefecture, Xinjiang. Based on this, evaluation and dynamic analysis of grassland health in Changji Prefecture from 2000 to 2016, using GIS/RS technology, the trend of grassland health status in Changji is analyzed and studied. The results show that: 1)Grassland with low health leveld, lower health level, sub-health level, health level and high health level accounts for $1.46 \%, 27.67 \%, 38.35 \%, 29.21 \%$ and $3.31 \%$ of the total area of Changji. Qitai County, Hutubi County, and Manas County are lower health levels, Jimsar County, Changji City, and Mulei County are at a relatively high level, and Fukang City has a healthy level of health. 2) The level of grassland health in Changji County decreased slightly during the 17 years, accounting for $38.42 \%$ of the total area. The area of $23,87 \%$ showed a stable trend, and the improved area accounted for $37.31 \%$ of the vertical surface area..
\end{abstract}

\section{INTRODUCTION}

Grassland is the largest ecosystem in China (Fu ZZ., 1996), the status of grassland is of great significance to the development of animal husbandry, biodiversity conservation, soil and water co nservation, and the maintenance of local ecological balance (Xi e GD., 2001). In addition, the grassland also has a variety of soc ial functions, the most common of which are economic and ecol ogical service functions (Min QW., 2004).

With the advancement of science and technology and people's increasing emphasis on grassland resources (Ren JZ., 2004), Scholars elaborated on the scientific definition of grassland and emphasized the relevance of grassland and other factors, to some extent overcome the limitations and bottlenecks in the study (Zhao YL., 2008; Zhao XL., 2008; Shan GL., 2008). Human activities have become the largest disturbance factor in grassland ecosystems (Cai XM., 2000). Grassland is an important carbon stock in ecosystems, quantitative qualitative monitoring of them helps to properly manage grassland resources and to take appropriate remedial measures in case of sudden disasters. Therefore, the study of grassland ecosystem health emerged.

Grassland health assessment is a relatively late start research are a. Since James Hutton and the British ecologist Arthur Tansley proposed the concept of "natural health" and "ecosystem" in 17 88 and 1935, respectively (Xiao FJ., 2002), more research based on this theory, the authors conducted a study on the structure a nd function of the ecosystem. The American scholar Dyksterhui s first proposed the concept of the "Range condition" in 1948, a nd further proposed the theory of the "Range Site" in 1949 (Dy ksterhuis E.J.,1949). In the 1960s, evaluation methods such as $g$ razing use, grassland management, and wild animals were adde $\mathrm{d}$ to the original evaluation, and the breadth of evaluation was $\mathrm{f}$ urther sublimated (Usa N.C., 1969). The "Man and Biosphere P roject"(MAB) that ended in the 1970s took the impact of distur bance factors on ecosystem effects as the main research content. On this basis, disturbance factors were also considered into the evaluation system (Concepts T., 1995). Until the 1980s, the UN Environment Committee put forward the concept of sustainable development in the texts such as "Protection of the Earth" and "Our Common Future" and introduced this concept into the gra ssland health assessment system. This period grassland health th e concept began to emerge. In the subsequent 1990s, an evaluati on system consisting of a combination of threshold and early wa rning indicators was highly praised by the National Advisory Ce nter and the Grassland Management Working Group (West N.E., 1994; Walker J., 1996; Pakeman R.J., 2010; Costanza R., 1997; Pellant M., 2005). Compared with the research progress abroad, domestic and grassland health related research started late, mos tly introducing and improving foreign exiting research and relat ed evaluation model construction forms. Li Bo proposed China based on grassland type succession built northern grassland deg radation grading index system (Li B., 1997). Since then, Hao D unyuan and Liu Zhongling have carried out more than 10 years of research on the degradation and diagnosis of grassland vegeta tion in 1997 and 1998 respectively, and in this basis, they have achieved certain research results (Liu ZL., 1997; Liu ZL., 1998). In 2000, Ren Jizhou established the threshold of health evaluati on based on the interface theory (Ren JZ., 2000). In 2005, Gao Anshe analysed the grassland health factors under different graz ing intensities and classified the evaluation results. The results were in good agreement with the actual conditions (Liu ZL., 19 97). Due to the differences in the research objects and the chara cteristics of the study area, the evaluation factors cannot be com pletely copied. Therefore, in the current stage of the evaluation

\footnotetext{
${ }^{1}$ Corresponding author: Email:zheng jianghua@126. com
} 
process, more methods and models are used for reference and se lection of indicators.

In view of the fact that animal husbandry is still the main econo mic model of Changji Grassland and lacks a certain degree of sc ientific management, the awareness of ecological protection of $r$ esidents in pastoral areas needs to be strengthened and the impl ementation of policies has not yet been evaluated in the future. Therefore, the ecological health status of Changji Grassland nee ds to be implemented. According to the evaluation, this study se lected and evaluated the indicators in the existing literature, and formed an evaluation index system to evaluate the health status of grassland in Changji Prefecture in June 2000-2016.

\section{RESEARCH AREA}

Xinjiang Changji Hui Autonomous Prefecture (herein referred t o as Changji Prefecture) (Li TS., 2005; Chen XJ., 2004; Mu Nir e.Hui Hemu, 2017) is located in the north of the Tianshan Mou ntains, the south-eastern edge of the Junggar Basin, and its nort h-eastern is adjacent to Mongolia. It is a core city on the world-f amous ancient Silk Road, the new $5^{\text {th }}$ North Road. Its geographi cal position occupies a strategic position in the development of $t$ he western region and is one of the first areas in the developmen $t$ of the economic belt on the northern slope of the Tianshan Mo untains in Xinjiang. It is an important window opening to the w est of Xinjiang and Urumqi. The mountainous area of the area a ccounts for $22.7 \%$ of the whole area, and the desert gobi accoun ts for $52 \%$ of the whole area. Therefore, the area can be divided into three major landscape units: mountainous, plain and desert (Mu Nire-Hui Hemu, 2017). It belongs to the middle temperate zone and has prominent continental features.

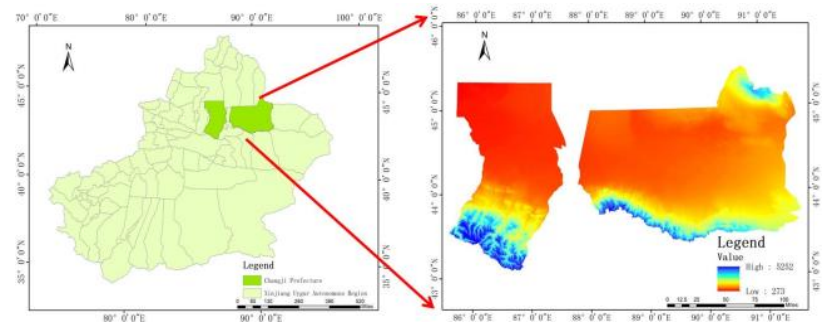

Figure 1.Location of Changji Prefecture

\section{DATA AND METHODS}

\subsection{Data Sources}

Remote Sensing Data: Remote Sensing data are sourced from th e Geospatial Data Cloud (http://www.gscloud.cn/). The remote s ensing data used for research in Changji Prefecture is formed by 10 image mosaics to meet the continuous June-July 2000-2016 period. In the analysis and study, a total of 114 remote sensing $i$ mages were used. The year of missing data was filled by years $t$ hat were adjacent and naturally consistent. The normalized vege tation index (NDVI) was produced from mosaic remote sensing images. According to Mu Shaojie (Mu SJ., 2013), Yang Hongfei (Yang HF., 2014) and Yang Huijin (Yang HJ., 2016), the appli cation resolution was $30 \mathrm{~m}$. The result of NDVI data participatio $\mathrm{n}$ calculation is $5 \%$ higher than that of $990 \mathrm{~m}$ NDVI data calcula tion. Therefore, this study uses higher resolution data to improv e the accuracy of this study.

Other map data: administrative division map of Changji Prefect ure, elevation data of Changji Prefecture, grassland type map of Changji Prefecture.
Meteorological and radiation data: average monthly temperature, monthly average precipitation and monthly average radiation.

Social economic data: Originated from Xinjiang Statistical Year book 2001-2017.

\subsection{Evaluation Model}

Grassland health assessment can characterize the status quo of $\mathrm{g}$ rassland for sustainable and rational development. In order to ac hieve a scientific evaluation of grassland health status, it must $c$ omply with scientific, systematic, dominant, quantifiable and op erability criteria when selecting evaluation indicators. Standards, to ensure that indicators can be deleted at the beginning of the $\mathrm{s}$ election are simple and have sufficient scientific value, to achie ve the evaluation index system, the evaluation results are reason able (Zhao CH., 2009; Chen MT., 2015; Xie XZ., 2013).

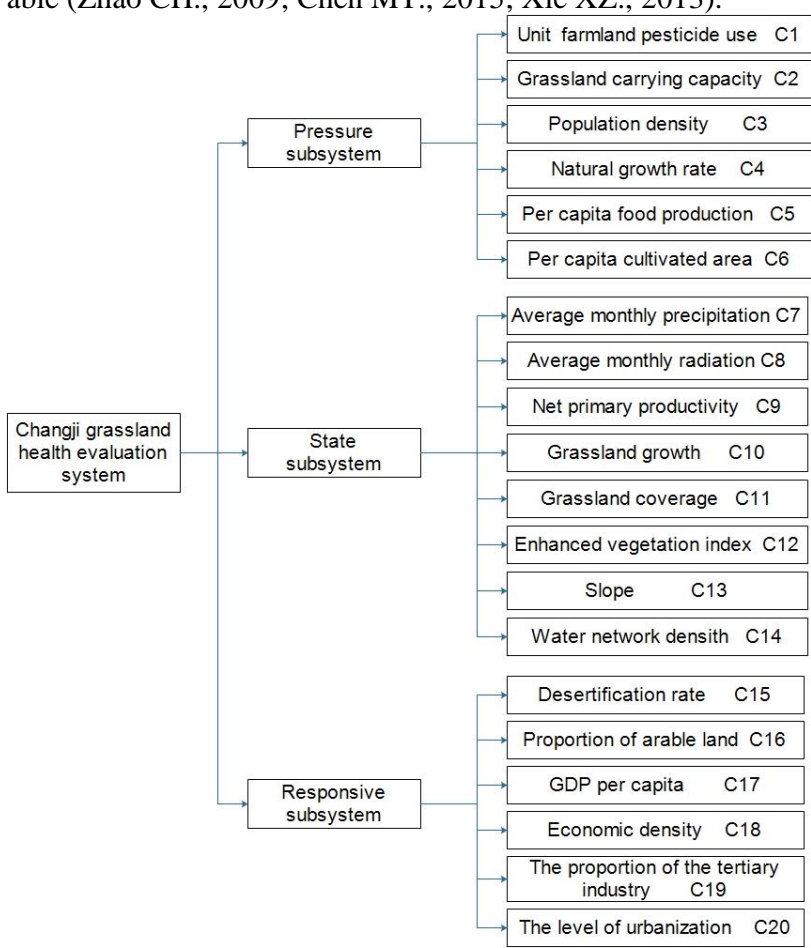

Figure 2.Assessment index system of grassland health in Changji prefecture

The PSR model has relatively few scientific applications to gras sland health (Zhao YT., 2016). In general, the evaluation using t he PSR model is based on a weighted sun of evaluation indicato rs to obtain a health assessment index, but based on the accumul ation of previous studies. The simple weighted summation cann ot achieve the result of a true scientific evaluation. Therefore, th e previous improved PSR health index calculation model was in troduced in order to make a more reasonable and scientific eval uation (Zhao YT., 2016). The calculation formula is as follows:

$$
\begin{gathered}
H I=\sqrt[3]{(1-P) \times S \times R} \\
\mathrm{P}=\mathrm{W}_{1} \mathrm{C}_{1}+\mathrm{W}_{2} \mathrm{C}_{2}+\mathrm{W}_{3} \mathrm{C}_{3}+\ldots+\mathrm{W}_{6} \mathrm{C}_{6} \\
\mathrm{~S}=\mathrm{W}_{7} \mathrm{C}_{7}+\mathrm{W}_{8} \mathrm{C}_{8}+\mathrm{W}_{9} \mathrm{C}_{9}+\ldots+\mathrm{W}_{14} \mathrm{C}_{14} \\
\mathrm{R}=\mathrm{W}_{15} \mathrm{C}_{15}+\mathrm{W}_{16} \mathrm{C}_{16}+\mathrm{W}_{17} \mathrm{C}_{17}+\ldots+\mathrm{W}_{20} \mathrm{C}_{20}
\end{gathered}
$$

where $H I=$ grassland health

$P, S, R=$ pressure, status, response subsystem score

$W=$ evaluation index weight

$C=$ evaluation index standard value 


\subsection{Determine The Weight}

Determining the weight is an important part of grassland health assessment. The weight of the index will directly affect the healt $\mathrm{h}$ evaluation results. The methods for determining weights can $b$ e roughly divided into subjectively determined weights and obje ctively determined weights. There are obvious different between the two methods. Compared to objectively determining the wei ghts can make a true and professional description of the actual $\mathrm{s}$ ituation in the study area from the perspective of experts. Howe ver, the cognitive differences among experts will cause the actu al situation to be subjective, although objectively determining th e method of weighting without expert cognition as a reference c annot reflect the actual situation in the region; it also fundament ally eliminates the subjective impact and can objectively obtain the results of grassland health assessment.

This paper chooses the weight of entropy method to calculate th e weight, entropy method is an objective method to determine th e right, according to the degree of variation of each index, the $u$ se of information entropy to calculate the entropy weight of the index through the entropy weight, thus obtain objective weights (Yu J., 2012), at the same time, calculate the weight of indicato rs on the basis of data standardization.

$$
W_{i}=\frac{1-e_{i}}{k-\sum e_{i}}
$$

where $\quad k=$ number of indicators

$\mathrm{e}_{\mathrm{i}}=$ information entropy

\subsection{Trend Analysis}

Trend analysis is a function that take times as an independent va riable, which also known as trend forecasting. This study selecte $\mathrm{d}$ a linear regression analysis to analyse the trend of grassland $\mathrm{h}$ ealth in Changji Prefecture from 2000 to 2016 (Lu ML., 2010; Rapport D.J., 1996; Yang Y., 2009).

$$
S=\frac{\mathrm{n} \times \sum_{i=1}^{n} i \times H I_{i}-\sum_{i=1}^{n} i \times \sum_{i=1}^{n} H I_{i}}{n \times \sum_{i=1}^{n} i^{2}-\left(\sum_{i=1}^{n} i\right)^{2}}
$$

where $s=$ slope value

$$
\begin{aligned}
& H I_{i}=\text { grassland health index } \\
& \mathrm{i}=\text { corresponding year } \\
& \mathrm{n}=\text { years }
\end{aligned}
$$

If the slope value is greater than 0 , the grassland health status of the area is improved. The larger the value, the more obvious th e improvement of the grassland health condition; if the slope val ue is less than 0 , the meaning is opposite. According to the tren $\mathrm{d}$ analysis calculation and data statistics, the corresponding relat ionship between the value range of slope and the change of gras sland health status is clear.

\begin{tabular}{|c|c|c|c|}
\hline $\begin{array}{l}\text { Target } \\
\text { level }\end{array}$ & $\begin{array}{l}\text { Criteria } \\
\text { layer }\end{array}$ & Indicator layer & Weight \\
\hline & & $\begin{array}{l}\text { Unit farmland pesticide } \\
\text { use }\end{array}$ & 0.02 \\
\hline & Pressure & $\begin{array}{l}\text { Grassland carrying } \\
\text { capacity }\end{array}$ & 0.008 \\
\hline
\end{tabular}

\section{GRASSLAND HEALTH ASSESSMENT RESULTS}

\subsection{Index Weight Calculation Results}

Table 1. Standard and weight of grassland health assessment index system in Changji prefecture

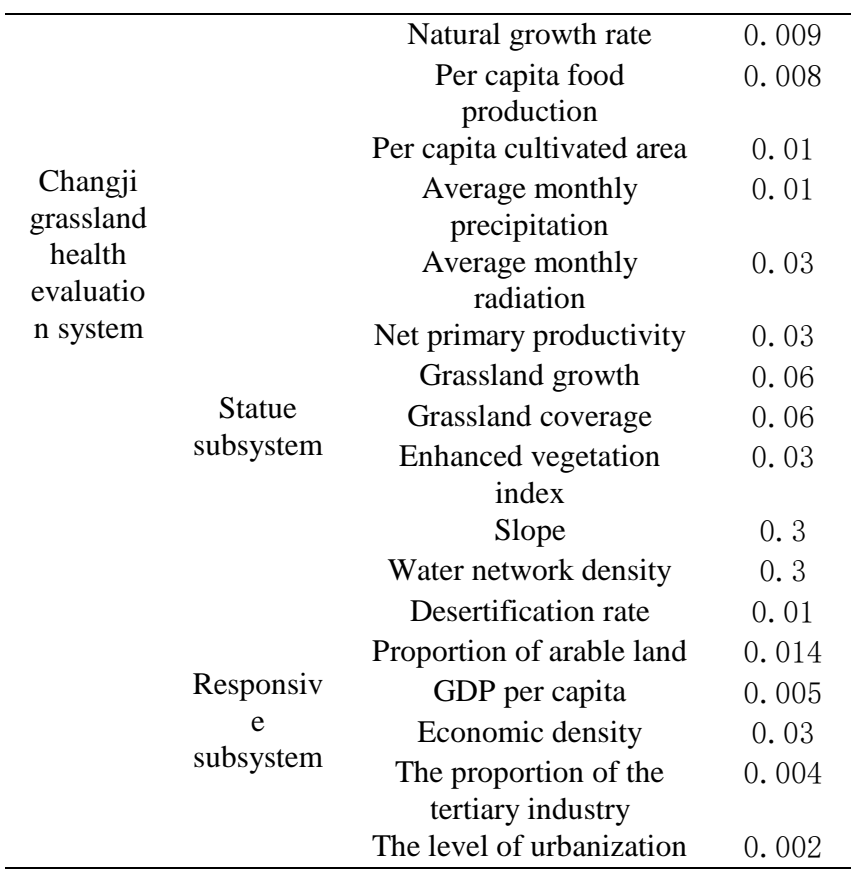

\subsection{Analysis of Chang of Grassland Health Time in Changji Prefecture}

According to the establishment of the evaluation criteria, the co mprehensive index of grassland health in Changji prefecture wa $\mathrm{s}$ graded using ArcGIS reclassification tools.

Table 2. Grade standard of grassland health assessment in Changji prefecture

\begin{tabular}{cc}
\hline Health level & Grassland health index \\
\hline High health level & $\mathrm{HI}>0.75$ \\
Health level & $0.55<\mathrm{H} \mathrm{I} \leqslant 0.75$ \\
Sub-health level & $0.25<\mathrm{H} \mathrm{I} \leqslant 0.55$ \\
Lower health level & $0.15<\mathrm{H} \mathrm{I} \leqslant 0.25$ \\
Low health level & $\mathrm{H} \mathrm{I} \leqslant 0.15$ \\
\hline
\end{tabular}

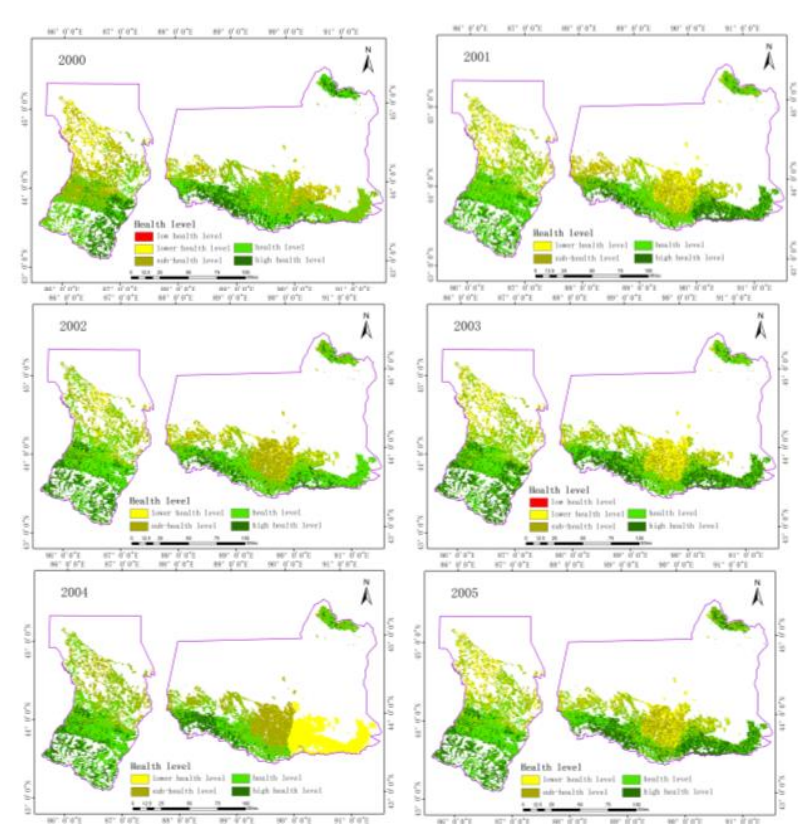




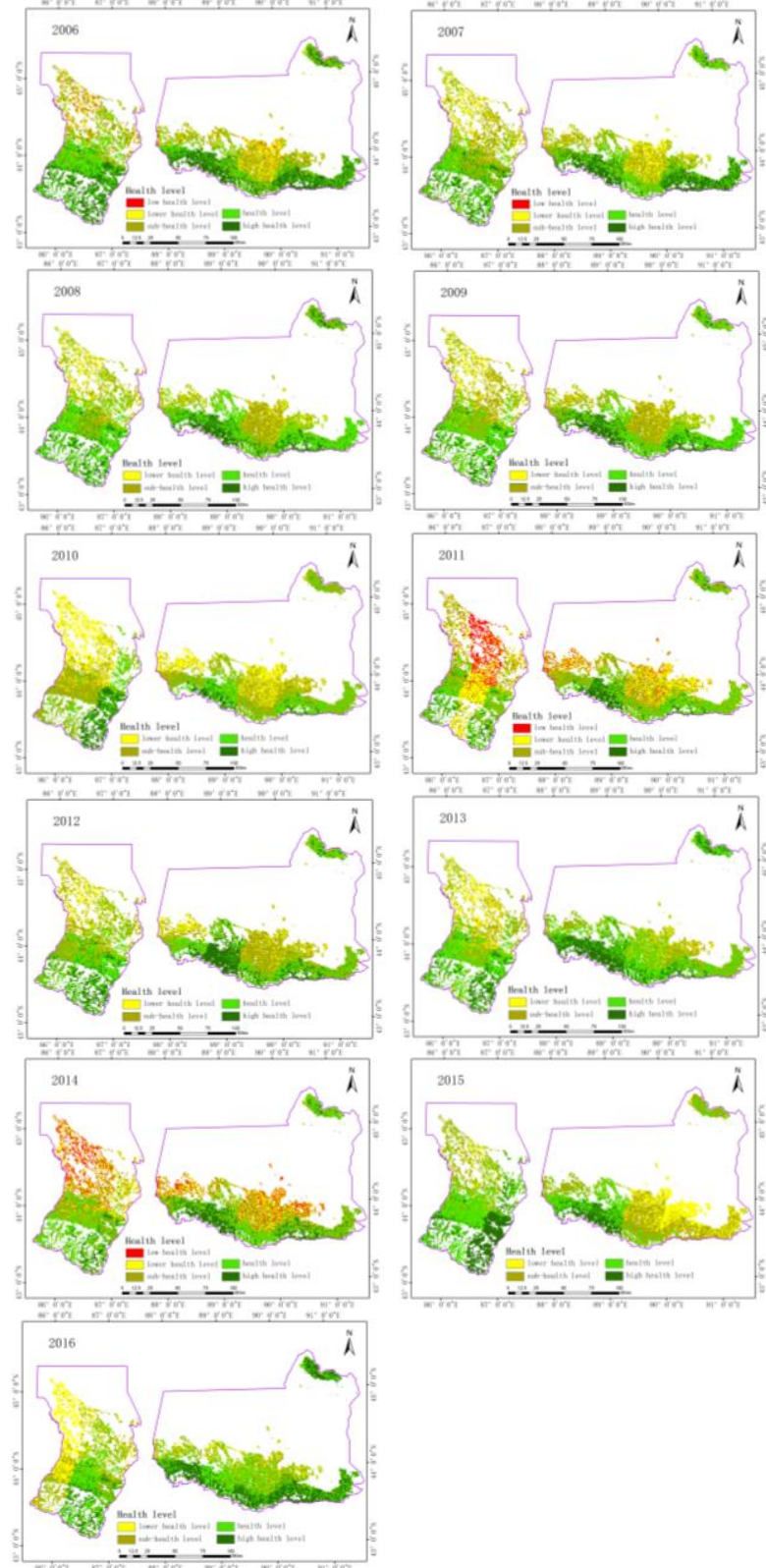

Figure 3.Health grading map of grassland ecosystem in Changji prefecture

Frome 2000 to 2016, the health status of grassland in Changji p refecture was mainly distributed in high, healthy, sub-healthy an $\mathrm{d}$ low health levels. Most of southern Changji prefecture areas were in healthy and high-healthy, the grassland health in the we stern region was low. Among them, there were only low health 1 evel areas in the grassland health level in 2000, 2003, 2006, 200 7, 2011 and 2014, the areas with low health levels in 2011 and 2014 were mostly found in Hutubi County and Manas County. I n 2004, most grassland in Mulei County and Qitai County exhib ited relatively low health levels. In 2016, most of the grasslands in Hutubi County exhibited lower health levels. In addition, the changes in the health status of grassland in other regions were st able.

The grassland health in Changji City has changed from 2000 to 2016. As a whole, Changji City's grassland health level showed a fluctuating trend, but the change was modest and basically re mained stable.
The change of grassland health in Fukang City from 2000 to 20 16 is complex, and its grassland health changes show a downwa rd trend. The health level of grassland in Fukang City has deteri orated since 2009. In 2013, the health level of grassland has pic ked up. It didn't show a high level of health until 2013, and the subsequent grassland in the region showed a lower level of healt $\mathrm{h}$ in 2014. The recovery began in 2015 . It can be seen that grass land in Fukang City has shown a low recovery capacity. Overall, the level of grassland health in Fukang City has declined.

Grassland health in Jimusar County has shown a stable trend sin ce 2000-2016 and is basically at a healthy level.

Grassland health in Qitai County has shown a downward trend s ince 2000-2016, and grassland health is low. During the 17 year $\mathrm{s}$ of research, there was frequent occurrence. Compared with flat areas, the health conditions of grasslands in high altitude areas were mostly healthy.

Grassland health in Mulei County showed a steady growth trend from 2000 to 2016, and grassland was mostly at a healthy level. It is worth mentioning that in 2004, the area showed a relativel y low level of health, which may be directly related to the intens ity of human activities and land use during the year.

Grassland health in Manasi County has shown stable fluctuation s since 2000-2016, and most grassland are in healthy and sub-h ealthy conditions. On the whole, the Manas grassland is in a stat e of stable fluctuation and the grassland recovery capacity is str ong.

The grassland health in Hutubi County showed a slow decline fr om 2000 to 2016, and most of the grasslands were in sub-health and low health levels. The grassland conditions in this area are basically toward a lower level of health development, and there is no certain year that can show a rebound in certain degree. It $c$ an be seen that the ability to restore grassland in Hutubi is week.

\subsection{Spatial Analysis of Grassland Health in Changji Region}

In order to characterize the distribution characteristics of grassla nd health in 17 years in Changji prefecture, ArcGIS software wa $\mathrm{s}$ used to calculate and map the distribution of grassland health $\mathrm{i}$ n Changji prefecture from 2000 to 2016.

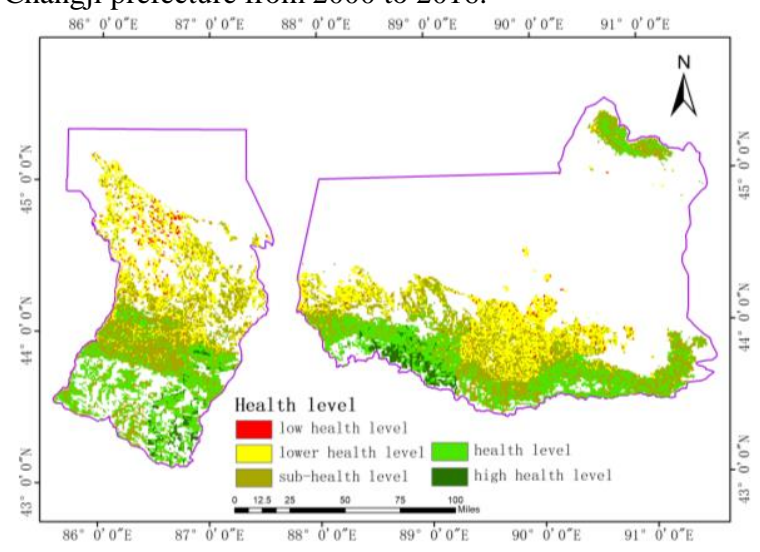

Figure 4.Spatial distribution of grassland ecosystem mean health in Changii prefecture between 2000 and 2016

The average spatial distribution of grassland health in Changji Grassland from 2000 to 2016 is shown in the figure. The health index ranges from 0.12375 to 0.82963 . The grassland health lev el showed a clear north-to-south height, and gradually increased 
along with the elevation; among them, Changji City, Fukang Ci ty, Jimsar County and Mulei County had higher levels of grassla nd health, and Manas County, The health level of grassland in Hutubi County and Qitai County is relatively low. Overall, acco rding to the grassland type map, the grassland area of Changii $\mathrm{P}$ refecture is $18.94504 \mathrm{~km}^{2}$, of which, Changji Prefecture, $1.46 \%$ of the grassland is of low health, $27.67 \%$ of the grassland is of 1 ower health, and $38.35 \%$ of grassland is of sub-health. $29.21 \%$ of grassland belongs to healthy level and $3.31 \%$ of grassland bel ongs to high health level.

According to the Changzhi County grassland health grading sta ndard and the spatial distribution statistics of the health index a bove, statistics were made on the grassland health status of each county and city. Among them, $40.64 \%, 37.56 \%$ and $36.73 \%$ of the grasslands in Qitai County, Hutubi County and Manas Coun ty respectively belong to low health level; $89.4 \%$ of Jimsar Cou nty, Changji City, Mulei County and Fukang City respectively. The grassland of $86.98 \%, 76.68 \%$ and $69.64 \%$ belonged to high er health level. The health status of grassland in Changji County was ranked in descending order of Jimsar County, Changji City, Mulei County, Fukang City, Manas County, Hutubi County an d Qitai County.

Table 3. Spatial distribution of grassland health in Changji prefecture counties and cities between 2000 and 2016 unite;\%

\begin{tabular}{ccccc}
\hline Health level & $\begin{array}{c}\text { Manas } \\
\text { County }\end{array}$ & $\begin{array}{c}\text { Hutubi } \\
\text { County }\end{array}$ & $\begin{array}{c}\text { Changji } \\
\text { City }\end{array}$ & $\begin{array}{c}\text { Fukang } \\
\text { City }\end{array}$ \\
\hline $\begin{array}{c}\text { Low health level } \\
\text { Lower health }\end{array}$ & 2.63 & 3.14 & 0.11 & 0.73 \\
level & & 34.42 & 12.91 & 29.63 \\
$\begin{array}{c}\text { Sub-health level } \\
\text { Health level }\end{array}$ & 36.34 & 47.41 & 30.51 & 34.38 \\
High health level & 26.93 & 14.89 & 46.06 & 32.81 \\
\cline { 1 - 4 } & & 0.14 & 10.41 & 2.45 \\
\hline Health level & Jimsar & Qitai & Mulei & \\
& County & County & County & \\
\cline { 1 - 3 } Low health level & 0.24 & 1.29 & 1.14 & \\
Lower health & 10.36 & 39.95 & 22.18 & \\
level & & & & \\
Sub-health level & 30.86 & 42.11 & 39.50 & \\
Health level & 41.95 & 17.25 & 37.18 & \\
High health level & 16.59 & & & \\
\cline { 1 - 3 }
\end{tabular}

Note:-—indicates the default value

\subsection{Analysis of Grassland Health Trends in Changji Prefecture}

According to the trend analysis calculation formula and the tren $\mathrm{d}$ level classification, the grassland health change trend chart in Changji prefecture was obtain.

Table 4. Statistical analysis on the result of grassland health trends in Changii Prefecture between 2000 and 2016

\begin{tabular}{clcc}
\hline Grassland health trends & $\begin{array}{l}\text { Degree } \\
\text { description }\end{array}$ & $\begin{array}{l}\text { Area } \\
\left(\mathrm{km}^{2}\right)\end{array}$ & $\begin{array}{l}\text { Area } \\
\text { ratio } \\
(\%)\end{array}$ \\
\hline Slope $\leqslant-0.0035$ & $\begin{array}{l}\text { Severe } \\
\text { deterioration }\end{array}$ & 0.9774 & 5.16 \\
$-0.0035<$ Slope $\leqslant-$ & $\begin{array}{l}\text { Moderate } \\
\text { deterioration } \\
0.0025\end{array}$ & 2.7531 & 14.53 \\
$-0.0025<$ Slope $\leqslant-$ & $\begin{array}{l}\text { Mild } \\
\text { deterioration } \\
0.0015\end{array}$ & 3.5496 & 18.73 \\
$-0.0015<$ Slope $\leqslant 0.0015$ & $\begin{array}{l}\text { Basically } \\
\text { unchanged }\end{array}$ & 4.5234 & 23.87 \\
\hline
\end{tabular}

\begin{tabular}{clcc}
\hline $0.0015<$ Slope $\leqslant 0.0025$ & $\begin{array}{l}\text { Mild } \\
\text { improvement }\end{array}$ & 4.4937 & 23.71 \\
$0.0025<$ Slope $\leqslant 0.0035$ & $\begin{array}{l}\text { Moderate } \\
\text { improvement }\end{array}$ & 1.9233 & 10.15 \\
Slope $>0.0035$ & $\begin{array}{l}\text { Significant } \\
\text { improvement }\end{array}$ & 0.7299 & 3.85 \\
\hline
\end{tabular}

From 2000 to 2016, the deteriorated grassland health status of C hangji County was slightly larger than that of the improved regi on. The deteriorated grassland accounted for $38.42 \%$ of the total grassland area of Changji State, with severe deterioration of 5.1 $6 \%$, moderate deterioration of 14.53 , and mild deterioration. 18 . $73 \%$; Grasslands with improved grassland health status account ed for $37.71 \%$ of the total grassland area of Changji, with mild i mprovement of $23.71 \%$ and moderate improvement of $10.15 \%$. The significant improvement was only $3.85 \%$, mostly concentra ted in high altitude areas.

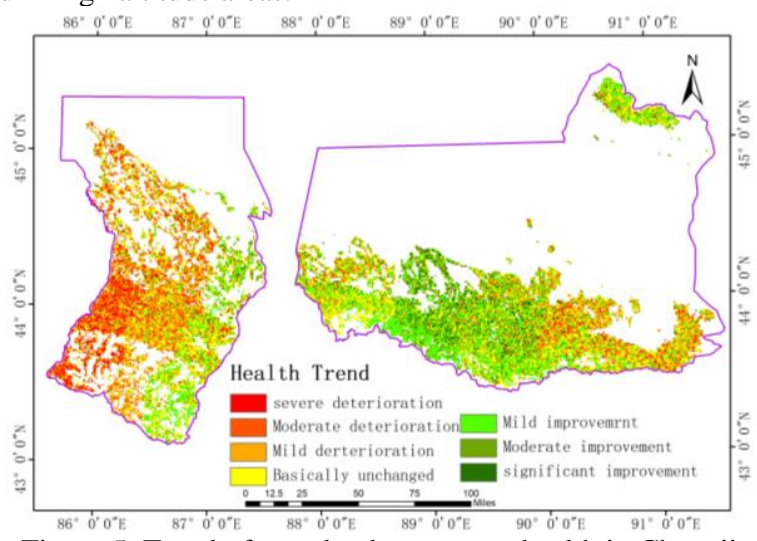

Figure 5. Trend of grassland ecosystem health in Changji prefecture between 2000 and 2016

Based on the analysis of grassland health trends in Changji Pref ecture, grassland health trends in the counties and cities under $t$ he jurisdiction of Changji Prefecture were analyzed with the sa me range of slope values, including grassland health in Changji City, Fukang City, Jimsar County, and Qitai County. With impr ovement, Changji City's grassland health improvement area acc ounted for $48.15 \%$ of the total grassland area in the city, and the slightly improved area was $33.45 \%$; the grassland health level i mprovement area in Fukang City accounted for $42.84 \%$ of the $t$ otal grassland area in the city, and the slight improvement area was 30.81. \%; The area of grassland health improvement in Jim usar County accounted for $84.77 \%$ of the total area of grassland in the county, the area of mild improvement was $37.64 \%$, and th e area of moderate improvement was $32.33 \%$; the area of grass and health improvement in Qitai County accounted for $59.56 \%$ of the total area of the grassland in the county, and the mild imp roved area was $35.24 \%$.

The grassland health conditions in Manasi County, Hutubi Cou nty and Mulei County have deteriorated, among which the deter iorated grassland in Manasi County accounted for $76.78 \%$ of th e total grassland area in the county, of which the slight deteriora tion rate was $23.18 \%$, and the deterioration was moderate. It wa s $34.04 \%$, with a severe deterioration of $19.56 \%$; the deteriorati on of grassland health in Hutubi County accounted for $65.94 \%$ of the total grassland area in the county, slightly worsened by 3 $0.94 \%$, moderately deteriorated by $29.04 \%$, and moderately dete riorated by $5.96 \%$; The deteriorated area of grassland in Lai Co unty accounted for $47.25 \%$ of the total grassland area of the cou nty, with a slight deterioration of $27.39 \%$, moderate deterioratio $\mathrm{n}$ of $14.68 \%$, and severe deterioration of $5.18 \%$. 
Table 5. Statistical analysis on the result of grassland health trends in Changji Prefecture counties and cities between 2000

\begin{tabular}{|c|c|c|c|c|}
\hline Health level & $\begin{array}{l}\text { Manas } \\
\text { County }\end{array}$ & $\begin{array}{l}\text { Hutubi } \\
\text { County }\end{array}$ & $\begin{array}{c}\text { Changji } \\
\text { City }\end{array}$ & $\begin{array}{c}\text { Fukang } \\
\text { City }\end{array}$ \\
\hline $\begin{array}{c}\text { Severe } \\
\text { deterioration }\end{array}$ & 19.56 & 5.96 & 0.78 & 1.22 \\
\hline $\begin{array}{l}\text { Moderate } \\
\text { deterioration }\end{array}$ & 34.04 & 29.04 & 4. 63 & 6.94 \\
\hline $\begin{array}{c}\text { Mild } \\
\text { deterioration }\end{array}$ & 23.18 & 30.94 & 12.27 & 15.70 \\
\hline $\begin{array}{l}\text { Basically } \\
\text { unchanged }\end{array}$ & 16. 23 & 23.08 & 34.17 & 33.30 \\
\hline $\begin{array}{c}\text { Mild } \\
\text { improvement }\end{array}$ & 5.48 & 8.99 & 33.45 & 30.81 \\
\hline $\begin{array}{l}\text { Moderate } \\
\text { improvement }\end{array}$ & 1.38 & 1.88 & 12.05 & 8.61 \\
\hline $\begin{array}{l}\text { Significant } \\
\text { improvement }\end{array}$ & 0.13 & 0.11 & 2.65 & 3. 42 \\
\hline Health level & $\begin{array}{l}\text { Jimsar } \\
\text { County }\end{array}$ & $\begin{array}{l}\text { Qitai } \\
\text { County }\end{array}$ & $\begin{array}{l}\text { Mulei } \\
\text { County }\end{array}$ & \\
\hline $\begin{array}{c}\text { Severe } \\
\text { deterioration }\end{array}$ & 0.23 & 0.92 & 5.18 & \\
\hline $\begin{array}{c}\text { Moderate } \\
\text { deterioration }\end{array}$ & 0.91 & 4.50 & 14.68 & \\
\hline $\begin{array}{c}\text { Mild } \\
\text { deterioration }\end{array}$ & 2.86 & 11.95 & 27.39 & \\
\hline $\begin{array}{l}\text { Basically } \\
\text { unchanged }\end{array}$ & 11.23 & 23.07 & 27.12 & \\
\hline $\begin{array}{c}\text { Mild } \\
\text { improvement }\end{array}$ & 37.64 & 35.24 & 20.98 & \\
\hline $\begin{array}{c}\text { Moderate } \\
\text { improvement }\end{array}$ & 32.23 & 16.88 & 3.78 & \\
\hline $\begin{array}{c}\text { Significant } \\
\text { improvement }\end{array}$ & 14.90 & 7. 44 & 0.87 & \\
\hline
\end{tabular}

\section{CONCLUSION}

Based on the time scale, the level of grassland health in Changji County experienced a first increase and then a decrease in the fi nal stable fluctuation from 2000 to 2016. During the period, the grassland health of Changji Prefecture fluctuates in varying degr ees. The grassland health status in Changji City is basically stab le and is in a stable state. Higher health level; grassland health i $\mathrm{n}$ Fukang City showed a declining trend; grassland in Jimusan C ounty was basically at a healthy level; grassland in Qitai County had a low level of health but grassland in high altitude areas in the region was at a healthy level; Mulei County Grassland is mo stly at a healthy level; grassland health in Hutubi County is on a downward trend.

Based on the spatial scale, the average grassland health index of Changji County in the period from 2000 to 2016 was 0.47673 ; the grasslands under its jurisdiction in Zhongqitai County, Hutu bi County, and Manas County were $40.64 \%, 37.56 \%$, and 36.7 $3 \%$ respectively. In the low health level, $89.4 \%, 86.98 \%$, and 76 $68 \%$ of the grasslands in Jimsar County, Changji City, and Mul ei County have higher health levels. The grassland health status of Changji Prefecture is ranked in descending order. Jimsar Cou nty > Changji City > Mulei County > Fukang City > Manas C ounty $>$ Hutubi County $>$ Qitai County.

Based on changes in trends, from 2000 to 2016, the deteriorated grassland in Changji County reached $38.42 \%$, with severe deter ioration of $5.16 \%$, moderate deterioration of 14.53 , and mild det erioration of $18.73 \%$. The deterioration of grassland health statu $\mathrm{s}$ was slightly greater than improvement. In the region, the overa 11 trend is slightly declining; According to the statistical data of counties and cities under the jurisdiction of the city, the grasslan $\mathrm{d}$ health in Changji, Fukang, Jimsar County, and Qitai counties has improved, and in Manas and Hutubi counties. The grassland health condition in Mulei County has been deteriorating. Throu gh comparative analysis, the grassland health status in Changji Prefecture has shown a slight downward trend, but more attenti on needs to be paid to prevent further degradation of the grassla nd health level.

\section{ACKNOWLEDGEMENTS}

Supported by 2016 XinJiang uygur autonomous region postgrad uate education reform innovation program (XJGRI2016015); Xi njiang uygur autonomous region youth science and technology $\mathrm{i}$ nnovation talent training project(2016); The XinJiang natural gr assland health evaluation system and evaluation model research based on the remote sensing and GIS technology 2015-2016(62 207)

\section{REFERENCES}

Cai XM., 2000. Ecosystem Ecology[M]. Science Press.

Concepts T., Members T.C., 1995. New Concepts for Assessm ent of Rangeland Condition[J]. Journal of Range Management, 48(3),pp.271-282.

Costanza R., D'Arge R., Groot R.D., 1997. The value of the wor ld's ecosystem services and natural capital[J]. Ecological Econo mics, 387(1),pp.3-15.

Chen XJ., 2004. Discussion on Urban Development in Changji Prefecture, Xinjiang[J]. Journal of Arid Land Resources and En vironment, 18(5), pp.89-92, doi: 10.3969/j.issn.1003-7578.200 4.05 .020

Chen MT., 2015. Preliminary Study on Early Warning of Land Ecological Security in Guangdong Province[D]. Graduate Univ ersity of Chinese Academy of Sciences (Guangzhou Institute of Geochemistry)

Dyksterhuis E.J., 1949. Condition and Management of Range L and Based on Quantitative Ecology[J]. Journal of Range Manag ement, 2(3), pp.104-115.

Fu ZZ., 1996. Chinese Agricultural Encyclopedia, Ornamental Horticulture Volume [M]. Agricultural Press.

Li B.,1997.Grassland Degradation and Countermeasures in Nort hern China[J]. Chinese Journal of Agricultural Sciences, 30(6), pp.1-9.

Liu ZL., Wang W., 1997. Study on restoration succession of gra ssland degraded communities in Inner Mongolia: mathematical model of community succession[J]. Chinese Journal of Plant Ec ology, 21(6), pp.503-511.

Liu ZL., Wang W., 1998. Models and Diagnosis of Degeneratio $\mathrm{n}$ Succession of Grassland Vegetation in Inner Mongolia Under Continuous Grazing Pressure[J].Actagraslanda Sinica, 6(4), pp. 244-251. 
Li TS., Zhang YS., Liu YG., 2005. Ecological Environment Co nstruction in Changji Prefecture, Xinjiang[J]. Journal of Northw est University: Natural Science Edition, 35(6), pp. 799-803, doi: 10.3321/j.issn:1000-274X.2005.06.032

Lu ML., 2010. Land use change characteristics and trends in $\mathrm{Ha}$ ihe River Basin[D]. Tianjin University, doi: 10.7666/d.y192545 9

Min QW., Xie GD., Hu Y., 2004. Evaluation of Grassland Ecos ystem Service Function in Qinghai Province[J]. Resources Scie nce, 26(3), PP.56-60,doi: 10.3321/j.issn:1007-7588.2004.03.00 9.

Mu Nire $\cdot H u i$ Hemu, 2017. DISCUSSION ON THE INDUSTRI ALIZATION OF ANIMAL HUSBANDRY IN CHANGJI, XIN JIANG[J]. herbivores, 2, pp.6-12, doi: 10.16863/j.cnki.1003-63 77.2017.02.002

Mu SJ., Li JL., Zhou W., 2013. Spatial-temporal pattern of net primary productivity and its relationship with climate in Inner Mongolia from 2001 to 2010[J]. Chinese Journal of Ecology, 3 3(12), pp.3752-3764, doi: 10.5846/stxb201205030638

Pakeman R.J., 2010.Restoration Ecology and Sustainable Devel opment[J]. Journal of Applied Ecology, 36(6),pp.1078-1079.

Pellant M., Shaver P., Pyke D., 2005. Interprinting indicators of rangeland health[M]. Colorado: Division of Science Integration Branch of Publishing Services(Version 4)

Ren JZ, 2004. General Theory of Grassland Agricultural Ecosys tem[M]. Anhui Education Press.

Ren JZ., Nan ZB., 2000. Interface Theory in Pratacultural Syste $\mathrm{m}[\mathrm{J}]$. Journal of Pratacultura Sinica, 9(1), pp.1-8,doi: 10.3321/j. issn:1004-5759.2000.01.001

Rapport D.J., L C., 1996. Gaudet, P Calow. Evaluating and Mo nitoring the Health of Large-Scale Ecosystems[J]. Journal of Ec ology, 83(6).

Shan GL., Xu Z., Ning F., 2008, Research progress and develop ment trend of grassland ecosystem health assessment[J]. Chines e Journal of Grassland, 30(2), PP.98-103.

Sun B., 2016. Research on Remote Sensing Recognition and Ev aluation of Degraded Land [D]. Chinese Academy of Forestry. Usa N.C.,1969. Rangeland health, New methods to classify, inv entory, and monitor rangelands.[C]// National Academy Press,p p.336-337.

Walker J., Reuter D., 1996. Indicators of Catchment Health[M]. West N.E., Mcdaniel K., Smith E.L., 1994. Monitoring and Inte rpreting Ecological Integrity on Arid and Semi-Arid Lands of th e Western United States[J].

Xiao FJ., Ouyang H., 2002. Ecosystem Health and Its Evaluatio $\mathrm{n}$ Indexes and Methods[J]. Journal of Natural Resources, 17(2), PP.203-209, doi: 10.3321/j.issn:1000-3037.2002.02.012

Xie GD., Zhang YL., Lu CX., 2001. Natural grassland ecosyste $\mathrm{m}$ service value in China[J]. Journal of Natural Resources, 16 (1), PP.47-53,doi: 10.3321/j.issn:1000-3037.2001.01.009.
Xie XZ., 2013.Research on Land Use Ecological Security of Do ngying City Based on RS and GIS[D]. Shandong Normal Unive rsity.

Yang HF., Gang CC., Mu SJ., 2014. Study on the Changes of N et Primary Production and Temporal and Spatial Patterns of Gra ssland Ecosystem in Xinjiang in Recent 10 Years[J]. Acta Prata culturae Sinica, 23(3), pp.39-50.

Yang HJ., Liu LJ., Ma JL., 2016. Size effect of inversion of net primary productivity in arid regions based on Landsat 8 remote sensing images[J]. Chinese Journal of Ecology, 35(5), pp.12941300, doi: 10.13292/j.1000-4890.201605.021

Yu J., Fang L., Cang DB., 2012. Application of entropy weight fuzzy matter-element model in land ecological security assessm ent[J]. Journal of Agricultural Engineering, 28(5), pp.260-266, doi: 10.3969/j.issn.1002-6819.2012.05.043.

Yang Y., Tang GA., Liu XJ., 2009. Theories, methods and appli cations of digital terrain analysis[J]. Acta Geographica Sinica, 6 4(9), pp.1058-1070, doi: 10.3321/j.issn:0375-5444.2009.09.004

Zhao XL., 2008. Study on Forest Ecosystem Health Assessment A Case Study of Forest Ecosystem in Chengde County[D]. Hebei Agricultural University,doi: 10.7666/d.y1307016.

Zhao YL., Long RJ., Lin HL., 2008. Grassland Ecosystem Secu rity and Its Evaluation[J]. Journal of Pratacultura Sinica, 17(2), PP.143-150, doi: 10.3321/j.issn:1004-5759.2008.02.020.

Zhao CH.,2009. Evaluation of Regional Ecological Security Ba sed on Land Use- Taking Ordos City as an Example[D]. Pek ing University.

Zhao YT., 2016.Dynamic Evaluation of Grassland Ecosystem H ealth in Gannan Prefecture in Recent 13 Years[D]. Lanzhou Uni versity. 